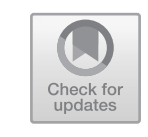

\title{
Muslim NGOs, Zakat and the Provision of Social Welfare in Sub-Saharan Africa: An Introduction
}

\author{
Holger Weiss
}

Muslim non-governmental organizations (NGOs) are a growing feature in many parts of sub-Saharan Africa with heavy influence on the societies in which they operate. Their impact is not only limited to the private sphere of the believers but extends to the public sphere as well. Public debates are impregnated by religiously inspired arguments. Striking examples of this development are the debates accompanying the role of Khadis' Courts in the so-called Bomas draft constitution referendum of Kenya in 2005 or the re-implementation of Islamic Law in Northern Nigeria starting in the early 2000s. ${ }^{1}$ Muslim NGOs are playing an important role in shaping public debates on issues related to the correlation of state and religion in the respective countries. Some Muslim NGOs, after being accused of supporting militant movements, have even been dissolved. Under pressure of the international community, many

\footnotetext{
${ }^{1}$ See further John A. Chesworth and Franz Kogelmann, eds., Sharî'a in Africa Today: Reactions and Responses (Leiden and Boston: Brill, 2013).
}

H. Weiss $(\square)$

Department of History, Åbo Akademi University, Turku, Finland e-mail: holger.weiss@abo.fi

(C) The Author(s) 2020

H. Weiss (ed.), Muslim Faith-Based Organizations and Social Welfare in Africa, https://doi.org/10.1007/978-3-030-38308-4_1 
states in Africa restricted the operational basis of Muslim NGOs after 9/11. Muslim NGOs are confronted with an increasing lack of trust. However, many of them play a pivotal role in providing social welfare. The perception of Muslim NGOs oscillating between supporting terrorism inspired by Islam and helping to overcome the marginalized role of Muslims in some African states is a reality.

The objective of this book is to give an overview on the discourses, agendas and actions of Muslim NGOs and activists to achieve empowerment of Muslim populations in contemporary sub-Saharan Africa. The crisis of secular nationalism since the late 1960s and the 1970s has created favourable conditions in the Muslim World for a religiously oriented reflection and mobilization that integrates individual salvation and self-realization with a commitment to community welfare. Morally and religiously inspired social action underlies the provision of services for the poor that the state often cannot efficiently provide, including basic health care and education. Such social action can be informally organized, based on affinities of shared habits, expectations, practices and interests. Religiously based charitable associations, such as Muslim NGOs, focusing on a wide array of services (medical, educational, family welfare and emergency assistance), play exactly such a role. They rest initially on ties of local trust and community, although they can also provide a base for subsequent political participation. However, secular Western development institutions have been rather reluctant in recognizing the potentials of Southern religious organizations working on development. Muslim institutions and leaders, if recognized at all, were regarded as intrinsically hostile to modernization or at least articulating a critical attitude to the Western world. This negative perspective changed during the early decades of the twenty-first century when multilateral and bilateral government agencies recognized religious leaders and organizations, including Muslim faith-based NGOs, as key partners to achieve the UN Millennium (and subsequent) Sustainable Development Goals. ${ }^{2}$ Islamic instruments to promote social welfare and humanitarian assistance, not

\footnotetext{
${ }^{2}$ United Nations Development Programme "Islamic Finance Partners," https://www. undp.org/content/undp/en/home/partners/islamic-finance.html (checked 6 August 2019). See further Wendy R. Tyndale, ed., Visions of Development: Faith-Based Initiatives (Abingdon, Oxon and New York: Routledge, 2016 [2006]), 166-168; Jonathan Benthall, Islamic Charities and Islamic Humanism in Troubled Times (Manchester: Manchester University Press, 2016).
} 
least through the collection and distribution of zakat or obligatory alms, have generated a significant amount interest both by Western academics and by development professionals. ${ }^{3}$

The emergence or development of a public sphere in sub-Saharan African countries is usually linked with the modern, postcolonial state and modern, Western-inspired associations and NGOs. Following Whitfield, the construction of 'civil society' is the outcome of a process in which donor agencies, international NGOs, the government and social organizations all actively engage in debates and activities in the public sphere and use their engagement in the public sphere to legitimize their actions. For the government, 'civil society' is a response to increasingly articulated demands from sections of society for greater representation and participation in policy-making. For donor agencies, 'civil society' is both a means and an end. For international NGOs, 'civil society' is the key to linking citizens around the world in common struggles. For social organizations, 'civil society' is a tool for mobilization and legitimation. With the construction of civil society follows a tendency towards its institutionalization. ${ }^{4}$

However, the concepts of the public sphere and civil society in a sub-Saharan African context have to be broadened as patterns of political and societal organization outside the formal state structures and Western-type NGOs have to be included as well. From a historical perspective, there existed already a well-defined public sphere and civil society in several colonies in British and French West Africa. From an African Islamic studies perspective, one could even argue that such a 'political sphere' is even older, including that of the formation of specific 'Muslim spheres' in pre-colonial African societies. In many regions, the establishment of a distinct 'Muslim sphere' was a consequence of the

${ }^{3}$ Chloe Stirk, An Act of Faith: Humanitarian Financing and Zakat, Development Initiatives Briefing Paper March 2015, available at http://devinit.org/wp-content/ uploads/2015/03/ONLINE-Zakat_report_V9a.pdf (checked 6 August 2019).

${ }^{4}$ Lindsay Whitfield, "Civil Society as Idea and Civil Society as Process: The Case of Ghana," Oxford Development Studies 31, no. 3 (2003): 390. For a critical discussion on NGOs and civil society in Africa, see Ebenezer Odabare, "Civil Society in Sub-Saharan Africa," in The Oxford Handbook of Civil Society, ed. Michael Edwards (Oxford: Oxford University Press, 2011), 183-194; Robert A. Dibie, ed., Non-Governmental Organizations (NGOs) and Sustainable Development in Sub-Saharan Africa (Lanham: Rowman \& Littlefield, 2008); Sabine Lang, NGOs, Civil Society, and the Public Sphere (Cambridge: Cambridge University Press, 2012). 
colonial policy of granting religious and cultural autonomy for Muslim groups. ${ }^{5}$ In predominantly postcolonial Muslim states, such as Senegal and Mali, the transfer to the postcolonial state was equivalent with Muslim politicians and administrators taking over the colonial state. In states with a substantial Muslim population, such as Nigeria, the postcolonial condition has been marked by intra-community clashes between various Sufi and Sunni groups as well as inter-community clashes between Muslim and Christian groups, resulting into a complex political-cum-religious landscape: Officially, Nigeria is a secular federal state that applies (Western) civil law but in twelve northern states, Muslim law and Muslim political and economic institutions, such as the religious police (hisba) and zakat (religious tax paid by Muslims), are enforced since $2000 .^{6}$

The purpose of the anthology is to outline and analyse articulations and actions of Muslim NGOs with a special focus on their instrumentalization of Islamic social finance instruments, namely sadaqa or voluntary almsgiving and donations; zakat or mandatory almsgiving; and waqf or pious endowments. Contemporary Islamic economists such as M. U. Chapra highlight the potential of Islamic social finance instruments to alleviate the sufferings of the extremely poor, namely those living on less than USD 1.25 per day according to UN definitions, and to take care of their basic needs. ${ }^{7}$ Various studies estimate that zakat amounts from USD 200 billion to USD 1 trillion per annum across the world or around USD 187 million among countries in the Organisation

\footnotetext{
${ }^{5}$ Roman Loimeier, Islamic Reform and Political Change in Northern Nigeria (Evanston, IL: Northwestern University Press, 1997); Rüdiger Seesemann and Benjamin Soares, "'Being as Good Muslims as Frenchmen': On Islam and Colonial Modernity in West Africa," Journal of Religion in Africa 39, no. 1 (2009): 91-120.

${ }^{6}$ See further Roman Loimeier, "Traditions of Reform, Reformers of Tradition: Case studies from Senegal and Zanzibar/Tanzania," in Diversity and Pluralism in Islam: Historical and Contemporary Discourses Amongst Muslims, ed. Zulfiqar Hirji (London: I.B. Tauris, 2010), 135-164; Paul M. Lubeck and Bryana Britts, "Muslim Civil Society in Urban Public Spaces: Globalization, Discursive Shifts, and Social Movements," in Understanding the City: Contemporary and Future Perspectives, eds. John Eade and Christopher Mele (Oxford: Blackwell, 2002), 305-334, as well as the contributions in Benjamin Soares and Réne Otayek, eds., Islam and Muslim Politics in Africa (New York: Palgrave Macmillan, 2007).

${ }^{7}$ M.U. Chapra, The Islamic Vision of Development (Jeddah: Islamic Research and Training Institute, Islamic Development Bank, 2008).
} 
of Islamic Cooperation (OIC). Therefore, not only Muslim states but also Muslim NGOs have turned their interest to mobilize zakat for poverty alleviation in Muslim majority countries as well as for international development and humanitarian projects. However, there exists no consensus among Muslim scholars about the organization of its collection; in some Muslim states, such as Indonesia, Malaysia, Pakistan and the Sudan, zakat is compulsory and collected by the state, whereas in others, such as Bangladesh, it is compulsory but organized through voluntary (non-state) private zakat organizations. ${ }^{8}$ In the United Kingdom and in the USA, zakat is voluntary and managed by NGOs, the Muslim Charities Forum in the former, the Zakat Foundation of America in the latter. Similarly, zakat is voluntary in South Africa and its collection and distribution is managed through an NGO, the South African National Zakah Fund. ${ }^{9}$ Zakat constitutes a form of vertical philanthropy in all cases above as it is formal, structuralized and institutionalized. Sadaqa, in turn, corresponds to horizontal philanthropy as it is organized through private, personalized and informal ways, commonly through self-help groups or mosque funds. However, there has been an expansion of vertical forms of philanthropy during the last decade due to the establishment of private foundations, trusts and corporate foundations by High Net-Worth Individuals or 'Muslim entrepreneurs' as well as community chests and foundations in many sub-Saharan countries. ${ }^{10}$

The term 'Muslim NGO' serves in this book as a collective denominator for associations, groups and organizations established and operated by Muslim activists. Such organizations are variously called 'Islamic Charities', 'Islamic NGOs', 'Islamic Social Institutions', 'Muslim NGOs' and 'Muslim

${ }^{8}$ Arskal Salim, The Shift in Zakat Practice in Indonesia: From Piety to an Islamic Socio-Political-Economic System (Chiang Mai: Silkworm Books, 2008); Salma Mohamed Abdalmunim Abdalla, Charity Drops: Water Provision and the Politics of the Zakat Chamber in Khartoum, Sudan (Berlin: LIT Verlag, 2017); Zenobia Ismail, Using Zakat for International Development. K4D Helpdesk Report (Birmingham: Birmingham University, 2018). For an overview, see Samiul Hasan, ed., Human Security and Philanthropy: Islamic Perspectives and Muslim Majority Country Practices (New York: Springer, 2015).

${ }^{9}$ Sofia Yasmin and Roszaini Haniffa, "Accountability and Narrative Disclosure by Muslim Charity Organisations in the UK," Journal of Islamic Accounting and Business Research 8, no. 1 (2017): 70-86; Zakât Foundation of America, The Zakât Handbook: A Practical Guide for Muslims in the West (Bloomington, IN: AuthorHouse, 2008).

${ }^{10}$ Enabling Environment of Philanthropy in Ghana (Accra: SDG Philanthropy Platform, United Nations Development Programme, 2017), 26. 
Faith-Based Organisations'. What they have in common is the 'Muslim' or 'Islamic' nature of their vision and mission for their activities. The core motive for engagement in and donating to a Muslim NGO is based on the Qur'an and the Hadith, namely thawab (reward) as well as fi sabil li-llah (for the sake of Allah) for pious deeds. Apart from being institutionally separate from the state and government, non-profit making, voluntary and formal, the characteristics Muslim NGOs are, according to Nejima, Harmsen and Akutusu, altruistic and philanthropic. In their minds, the concern with the afterlife is a core motivation for members and donors of Muslim NGOs. To give and serve the needy is defined as both a moral and social duty and is supposed to counter one's greed and egoism and to have a morally purifying effect." However, as Yonathan N. Gez argues in chapter "Who Do FBOs Speak For? The Condundrum of Representation", research on lived religion informs us of a substantial gap between institutional narratives and de facto human practice. All around the world, people's everyday religious lives are in tension with such institutional ideals, whereby lay practitioners draw on different strands of tradition, combine and compromise between multiple, ever-negotiated practices, and create their own dynamic rhythms. We thus note a tension: religious organizations, in their essentialization of their flock, portray a vision that is prescriptive rather than descriptive and is often no more than wishful thinking.

A general typology of faith-based organizations is provided by Clarke who identifies five types of FBOs. The first one is Faith-based representative organizations or apex bodies. None of the Muslim FBOs are included among these organizations as no single organizations represent the Muslim faith globally. Instead, Muslim FBOs are identified as Faithbased charitable or development organizations, Faith-based socio-political organization, Faith-based missionary organizations or Faith-based illegal or terrorist organizations. Both Muslim charitable or development organizations and Muslim missionary organizations aim at the eradication of poverty by funding or managing programmes that help the poor and by raising awareness of poverty among the faithful. ${ }^{12}$ However, not all

\footnotetext{
${ }^{11}$ Susumu Nejima, Egbert Harmsen and Masayuki Akutsu, "Introduction," in NGOs in the Muslim World: Faith and Social Services, ed. Susumu Nejima (London and New York: Routledge, 2016), 3-6, 12.

${ }^{12}$ Gerard Clarke, "Faith Matters: Faith-Based Organisations, Civil Society and International Development," Journal of International Development 18 (2006): 840-843; also Gerard Clarke, "Faith-Based Organisations and International Development: An
} 
Muslim NGOs openly declare to be a faith-based organization as they do not want to be identified as an organization for political achievement, financing militant organizations or even being mixed up with militant Islamic organizations. Others are cautious in religious self-labelling in order to maintain a good relationship with the respective state and government authorities, as is the case in Turkey and Iran. ${ }^{13}$ LeBlanc and Gosselin, therefore, propose a distinction between faith-based NGOs who are either affiliated to a religious institution or are at least partially defined by religious faith and other kinds of religious institutions that can be described as FBOs. ${ }^{14}$

\section{Muslim NGOs in Sub-Saharan Africa}

Intra- and inter-community cohesion in non-Muslim states takes a different form than in Muslim states or in secular states with a Muslim majority. In North Africa and the Horn of Africa, the Near East, Iran, Pakistan, Bangladesh and Indonesia, Muslims constitute the absolute majority of the population and the state defines itself as a Muslim state where Muslim Sharia Law is applied either fully or partially. In several West and North-Central African states, such as Senegal, Mali, Niger, Nigeria, Cameroon and Chad, Muslims constitute either a substantial majority of the population or a dominant community in society. In most sub-Saharan African countries, however, Muslim communities constitute minority groups with complex relations to both non-Muslim religious communities and the secular state. In addition, there is a marked difference among the individual 'Muslim spheres' and the political discourses within these spheres. The crucial explanation is the historical

Overview," in Development, Civil Society and Faith-Based Organisations: Bridging the Sacred and the Secular, eds. Gerard Clarke and Michael Jennings (Basingstoke and New York: Palgrave Macmillan, 2008), 17-45. For a general discussion on Muslim NGOs and their comparison with Christian inspired relief NGOs, see Carlo Benedetti, "Islamic and Christian Inspired Relief NGOs: Between Tactical Collaboration and Strategic Difference?," Journal of International Development 18 (2006): 849-859.

${ }^{13}$ Nejima, Harmsen and Akutsu, "Introduction," 3.

${ }^{14}$ Marie Natalie LeBlanc and Louis Audet Gosselin, "Introduction: Faith, Charity and the Ethics of Voluntarism in West Africa," in Faith and Charity: Religion and Humanitarian Assistance in West Africa, eds. Marie Natalie LeBlanc and Louis Audet Gosselin (London: Pluto Press, 2016), 194, fn 4. 
development and expansion of each of these 'Muslim spheres', their interconnectedness with other 'Muslim spheres', the networks and flows between these spheres and its actors. ${ }^{15}$

Muslim NGOs and especially Muslim faith-based NGOs are, as LeBlanc and Gosselin note, products of neoliberal globalization. Starting with the economic and political crisis of the postcolonial sub-Saharan African states in the late 1970s, NGOs have taken over a significant responsibility for services that had previously been provided by the state, especially in education, health care and public safety. This 'NGO-ization' of associations and religious groups, LeBlanc and Gosselin underline, resulted in the extension of the formal (Western) NGO model to a vast array of civic and religious organizations which hitherto had not identified themselves as NGOs. On the other hand, the virtual explosion of small-scale associations and faith-based NGOs also reflects in their mind the increased visibility of religion and religious activists on both the political sphere and the logics of social development. ${ }^{16}$ In addition, the 'NGO-ization' is a result of the 'hollowing out' of the state in the wake of neoliberal globalization where the state has transferred some capacities to other levels such as international bodies at the regional and local level inside its territory and horizontal networks that bypass states and interlink localities in several localities. As Tok and O'Brien highlight, Muslim as well as other faith-based NGOs are fundamental examples of this 'hollowing out'. ${ }^{17}$ The process and impact of NGO-ization is further discussed by Marie Natalie LeBlanc in chapter "Charity, ONG-ization and

\footnotetext{
${ }^{15}$ See further Robert Launay and Benjamin F. Soares, "The Formation of an 'Islamic Sphere' in French Colonial West Africa," Economy and Society 28, no. 4 (1999): 497-519; Sean Hanretta, Islam and Social Change in French West Africa: History of an Emancipatory Community (Cambridge: Cambridge University Press, 2009); Roman Loimeier, Muslim Societies in Africa: A Historical Anthropology (Bloomington, IN: Indiana University Press, 2013); Roman Loimeier, Islamic Reform in 20th Century Africa (Edinburgh: Edinburgh University Press, 2016); Marie Natalie LeBlanc and Louis Audet Gosselin, eds., Faith and Charity: Religion and Humanitarian Assistance in West Africa (London: Pluto Press, 2016).

${ }^{16}$ LeBlanc and Gosselin, "Introduction," 2, 5. Also Marie Natalie LeBlanc and Benjamin Soares, eds., Muslim West Africa in the Age of Neoliberalism (Bloomington, IN: Indiana University Press, 2008).

${ }^{17}$ M. Evren Tok and Ben O’Bright, "Reproducing Spaces of Embeddedness Through Islamic NGOs in Sub-Saharan Africa: Reflections on the Post-2015 Development," African Geographical Review 36, no. 1 (2017): 85-99.
} 
Emergent Ethics of Volunteerism: The Case of Islamic NGOs in Côte d'Ivoire", by Valeria Saggiomo in chapter "Islamic NGOs in Somalia and their Role in the Somali State-Building Process" and by Sebastian Müller in chapter "Enterprisation of Islamic FBOs': Towards a New Typology of Islamic Non-Governmental Organisations in Consideration of Their Multiple Relatedness".

Muslim NGOs proliferated in sub-Saharan Africa during the 1990s due to political reform and economic liberalization (in most cases), or state fragility and collapse (in a minority of cases such as Palestine or Somalia). Following Kaag, Muslim faith-based NGOs based themselves on an understanding of Islamic solidarity that is composed of three elements: ighatha or humanitarian relief; $d a^{\prime} w a$ or Islamic call; and jihad in the sense of armed support of the Islamic cause. ${ }^{18}$ In comparison with Western/non-faith NGOs and Christian FBOs, the engagement of Muslim faith-based NGOs was for a long time left unnoticed by most observers. Only after the traumatic experiences in the West of radical militant Islamic organizations, the activities of Muslim faith-based NGOs have come under close scrutiny, both in the West as elsewhere in the world. ${ }^{19}$ Since 2001, at least four types of transnational Muslim faith-based NGOs active in Africa have been identified: da'watist, jihadist, solidarity-based and secularized. ${ }^{20}$ Some Muslim faith-based NGOs are identified as potential supporters of al-Qaeda and ISIS, others of posing a potential challenge, if not threat, to the Western secular state model. ${ }^{21}$ While the impact of Muslim faith-based NGOs is noted in the

\footnotetext{
${ }^{18}$ Mayke Kaag, "Aid, Umma, and Politics: Transnational Islamic NGOs in Chad," in Islam and Muslim Politics in Africa, eds. Benjamin F. Soares and René Otayek (Basingstoke and New York: Palgrave Macmillan, 2007), 85-102.

${ }^{19}$ M.A. Mohammed Salih, Islamic NGOs in Africa: The Promise and Peril of Islamic Voluntarism (Copenhagen: Centre of African Studies, University of Copenhagen 2001; revised version 2002); J. Millard Burr and Robert O. Collis, Alms for Jihad: Charity and Terrorism in the Islamic World (Cambridge: Cambridge University Press, 2006).

${ }^{20}$ Marie Juul Petersen, "Trajectories of Transnational Muslim NGOs," Development in Practice 22, nos. 5-6 (2012): 763-778.

${ }^{21}$ Valeria Saggiomo, "Islamic NGOs in Africa and Their Notion of Development: The Case of Somalia," Storicamente 8 (2012): 1-12; Marie Juul Petersen, "International Muslim NGOs: 'Added Value' or an Echo of Western Principles and Donor Wishes?," in The New Humanitarians in International Practice: Emerging Actors and Contested Principles, eds. Zeynep Sezgin and Dennis Dijkzeul (London and New York: Routledge 2016), 259-281.
} 
modernization of Islamic education in Africa, ${ }^{22}$ less noted has been the rise of the rapidly evolving religious media scene in Africa, in particular connected with the activities of Muslim faith-based NGOs or the multiple ways Muslims and Christians have encountered each other, borrowed or appropriated from one another, ${ }^{23}$ or tried to establish a room for an inter-faith dialogue. ${ }^{24}$

There has also been an increase of Islamic organizations committed to tabligh wa-da'wa, preaching the message of Allah, internationally since the 1990s. Arab organizations, including the World Muslim League (Saudi Arabia) and Direct Aid (formerly known as African Muslim Agency, Kuwait), support local madrasas (Islamic seminars or religious schools), and promote conservative Islamic currents such as Wahhabism and Salafism throughout sub-Saharan Africa. ${ }^{25}$ Many, if not most national and international Muslim faith-based NGOs, rely on zakat and therefore restrict their support largely to Muslim beneficiaries, as discussed by Mayke Kaag and Soumaya Sahla in chapter "Reflections on Trust and Trust Making in the Work of Islamic Charities from the Gulf region in Africa”. In addition, especially Saudi-Arabian relief and development organizations tend to support projects and activities of Salafi organizations and groups in African countries. ${ }^{26}$ Qatari Muslim faith-based NGOs, on the other hand, have emerged as a balancing factor between market liberalism and social protectionism in sub-Saharan Africa. ${ }^{27} \mathrm{~A}$ few Muslim faith-based NGOs do not highlight elements of da'wa, such as Islamic Relief and Muslim Aid. Instead, these organizations renounce proselytism and emphasize the creation of capabilities for

\footnotetext{
${ }^{22}$ See further Robert Launay, ed., Islamic Education in Africa: Writing Boards and Blackboards (Bloomington, IN: Indiana University Press, 2016).

${ }^{23}$ See further Rosalind J. Hackett and Benjamin F. Soares, eds., New Media and Religious Transformations in Africa (Bloomington, IN: Indiana University Press, 2015).

${ }^{24}$ See further Benjamin Soares, ed., Muslim-Christian Encounters in Africa (Leiden: Brill, 2006).

${ }^{25}$ Clarke, "Faith Matters," 844.

${ }^{26}$ Mohammed R. Kroessin and Abdulfatah S. Mohamed, "Saudi Arabian NGOs in Somalia: 'Wahhabi' Da'wah or Humanitarian Aid?," in Development, Civil Society and Faith-Based Organisations, eds. Gerard Clarke and Michael Jennings (Basingstoke and New York: Palgrave Macmillan, 2008), 187-213.

${ }^{27}$ Tok and O'Bright, "Reproducing Spaces of Embeddedness.”
} 
the poor in general rather than empowering individual Muslims. ${ }^{28}$ Over the years, many Muslim faith-based NGOs evolved towards professionalization; some developed a more humanitarian outlook, others became more politically active. ${ }^{29}$ Most Muslim faith-based NGOs operating on the national level in Africa are often supported by transnational Muslim faith-based NGOs and by Muslim governments, notably the Gulf States and-before 2011-Libya. ${ }^{30}$ Recently, Turkish NGOs have also started to operate in sub-Saharan Africa. ${ }^{31}$ Last but not least, the trademark of modern Muslim faith-based NGOs seems to be their use of Western vocabulary as well as modern techniques-above all the Internet, thus being in the end equal to Western NGOs in terms of objectives and means. ${ }^{32}$

The various roles of Muslim faith-based NGOs in sub-Saharan Africa are discussed in several chapters in the anthology. Mayke Kaag and Soumaya Sahla evaluate the social welfare projects of International Muslim NGOs/transnational Muslim charities from the Gulf region in Chad, Ghana and Senegal in chapter "Reflections on Trust and Trust Making in the Work of Islamic Charities from the Gulf region in Africa". In line with similar studies, they argue that in terms of what they are able to achieve in the social, political and religious sphere, is

\footnotetext{
${ }^{28}$ Marie Juul Petersen, For Humanity or For the Umma? Aid and Islam in Transnational Muslim NGOs (London: Hurst, 2015), 139-140.

${ }^{29}$ Sebastian Müller, "Krisen und Glaube - Streiflichter islamischer Nothilfe und langfristiger Entwicklungsmaßnahmen im Namen des Islams," in Krisenbilfe oder Hilfe in Krisen? Entwicklungszusammenarbeit mit Krisenländern, eds. Rainer Öhlschläger und Hartmut Sangmeister (Baden-Baden: Nomos 2016), 97-116.

${ }^{30}$ Chanfi Ahmed, "Networks of Islamic NGOs in Sub-Saharan Africa: Bilal Muslim Mission, African Muslim Agency (Direct Aid), and al-Haramayn," Journal of Eastern African Studies 3, no. 3 (2009): 426-437; Olakunle Odumosu, Rasheed Olaniyi and Sunday Alonge, Mapping the Activities of Faith-Based Organizations in Development in Nigeria, Religions and Development Research Programme Working Paper 38 (Birmingham: International Development Department, University of Birmingham, 2009); Cecilia Lynch, "Local and Global Influences on Islamic NGOs in Kenya," Journal of Peacebuilding of Development 6, no. 1 (2011): 21-34; Petersen, For Humanity or For the Umma?

${ }^{31}$ Abdurrahman Siradag, "Benevolence of Selfishness: Understanding the Increasing Role of Turkish NGOs and Civil Society in Africa," Insight on Africa 7, no. I (January 2015): 1-20.

${ }^{32}$ For a detailed outline, see Petersen, For Humanity or For the Umma?
} 
strongly influenced by the local and national contexts in which they come to work. In chapter "Charity, ONG-ization and Emergent Ethics of Volunteerism: The Case of Islamic NGOs in Côte d'Ivoire", Marie Natalie LeBlanc examines the recent growth and institutionalization of Islamic voluntary, humanitarian and charity actions in La Côte d'Ivoire. While local Islamic NGOs attempt to fit with professionalizing criteria required to have access to development programs' funds and policy planning (at the national and international levels), their actions are framed within local notions of piety and reflect how religious actors have gained significant influence on the logics of development. Valeria Saggiomo examines in chapter "Islamic NGOs in Somalia and Their Role in the Somali State-Building Process" the relationship between Islamic NGOs and the Islamist movements in Somalia which, in the wake of the fall of the Siad Barre regime, became dominant in the country's political panorama, such as the Somali Islamist movement Al Islah. In the absence of a formal state able to oversee social policy, Islamic NGOs took steps to compensate for the lack of a proper government, particularly in the provision of social services such as education and health. However, as Suleiman Athuman Chembea notes in chapter "Between Charity and Financing 'Terror': The Dilemma of Muslim Charitable Organizations in Kenya", following 9/11 and the subsequent 'war against terror', Muslim charitable organizations have bared the brunt of security apparatus allegedly for abetting terror. While the concerns for global security cannot be ignored, drawing examples from Kenya, this chapter argues that profiling Muslim charitable organizations breeds contempt and 'Relative Deprivation' pushing beneficiaries to the radical cells that security agencies and policies purport to fight. Sebastian Müller, in turn, focuses on chapter "'Enterprisation of Islamic FBOs': Towards a New Typology of Islamic Non-Governmental Organisations in Consideration of Their Multiple Relatedness" on the local frameworks and contexts that are shaping Muslim faith-based NGOs in Tanzania. Apart from Sunni NGOs, the anthology also covers the activities of non-Sunni Muslim NGOs; Mara Leichtman outlines the background and activities of Shi'i NGOs in Tanzania in chapter "Transnational Networks and Global Shi'i Islamic NGOs in Tanzania" while Katrin Langewische discusses the outreach of Ahmadi NGOs in West Africa in chapter "Politics of Humanitarianism: The Ahmadiyya and the Provision of Social Welfare". 


\section{Almsgiving Within the [Sunni] 'Muslim Sphere'33}

Contemporary debates in the 'Muslim sphere'-be it in sub-Saharan Africa or elsewhere-about poverty alleviation concentrate to a large extent on obligations and responsibilities. To understand the discourse of Muslim scholars, one has to acknowledge the fact that a Muslim articulation and analysis of contemporary problems rests on Islamic traditions, i.e. the standpoint of tawhid (unity) of religion and politics. While this section-in addition Holger Weiss' outline of the discourse on zakat in Ghana in Chapter Thirteen-concentrates on the Sunni discourse, other Muslim articulations about almsgiving and social welfare, such as those of the Shi'a and the Ahmadiyya in sub-Saharan Africa, are discussed by Mara Leichtman and Katrin Langewische in their respective chapters.

Obligations and responsibilities are interpreted within the normative concepts of Islam. Islam makes a normative distinction between obligatory and voluntary alms. Both the rich and the poor are addressed, i.e., the giver and the recipients of assistance. However, though almsgiving is an obligation that constitutes one of the five pillars of Islam, it is difficult to present a clear-cut definition. The main reason for the ambiguity of the term is due to the two ways in which almsgiving is interpreted in Islam, namely as zakat or obligatory alms, and sadaqa or voluntary alms. Sunni Muslim scholars commonly define zakat as a form of charity, almsgiving, donation or contribution, but when these activities are arbitrary and voluntary actions, they are merely regarded as sadaqa. The (proper) management of zakat, in turn, is identified as the cornerstone of an Islamic solution to poverty. ${ }^{34}$

One must further distinguish between the moral obligation and the pious act when one discusses the difference between the two kinds of almsgiving in Islam. Zakat is a moral obligation and becomes a tax for the Muslims in an Islamic state whereas sadaqa is an individual, pious

\footnotetext{
${ }^{33}$ The following section is based on Holger Weiss, Begging and Almsgiving in Ghana: Muslim Positions Towards Poverty and Distress (Uppsala: Nordiska Afrikainstitutet, 2007), 19-25 and 29-30.

${ }^{34}$ See further Yusuf al-Qardawi, Fiqh az-Zakat. A Comprehensive Study. The Rules, Regulations and Philosophy of Zakat in the Light of the Qur'an and Sunna (London: Dar Al Taqwa, 1999); World Bank and Islamic Development Bank Group, Global Report on Islamic Finance-Islamic Finance: A Catalyst for Shared Prosperity? (Washington, DC: World Bank Group, 2016), 174-175. For a general introduction, see Amy Singer, Charity in Islamic Societies (Cambridge: Cambridge University Press, 2008).
} 
act and never has any collective connotations. However, zakat is paid through the state, never as a tax to the state; that is, the role of the state is to monitor the levy and distribution of zakat but may not itself use the incomes of zakat for any other purpose not specified in the Qur'an (see below). ${ }^{35}$ A common interpretation among Muslim jurist-cum-scholars is that $2.5 \%$ of one's income and wealth (and between 5 and $10 \%$ of one's harvest) should be given the poor and needy as zakat. The collected amount is to be managed and distributed by the Bait al-mal or (state) treasury for the welfare (maslaha) of the umma, the community of believers (i.e. Muslims). ${ }^{36}$ Thus, zakat is more than just a 'good deed' because it is an obligation whereas the giving of alms (sadaqa) is the decision of the giver alone. Therefore, in an Islamic order, ideally zakat belongs to the public sphere and sadaqa belongs to the private. In addition to zakat and sadaqa, Muslims are required to pay zakat al-fitr or the mandatory alms given by breaking the fasting at the end of Ramadan. These alms are levied on persons only, not on wealth or income. ${ }^{37}$

Zakat is regarded by Muslim scholars as a means for the purification of wealth. Irrespective of the use of the proceeds of zakat, a Muslim is taught that zakat purifies legally acquired wealth. Put theologically, zakat is a portion due to Allah. Its collection and distribution is clearly regulated by the Qur'ān and by Islamic Law. The objective of zakat is to purify the soul of a Muslim from greed and miserliness. It is understood as a means of training Muslims on the virtues of generosity: Being paid in a repetitive pattern year after year, regular zakat as well as zakat al-fitr is claimed to train Muslims to give and spend for charitable purposes. ${ }^{38}$ Though Muslim jurists and scholars have established very precise regulations for the collection of zakat, their position towards the distribution of it has been rather vague. In most cases, scholars and jurists seem to be satisfied that the recipients of zakat are the eight categories

${ }^{35}$ Farishta G. de Zayas, The Law and Philosophy of Zakat (The Islamic Social Welfare System) (Damascus: Al-Jadidah Printing Press, 1960), 281-282.

36 'Abdur Rahman I. Doi, Sharîa 388.

${ }^{37}$ al-Qardawi, Fiqh az-Zakat, 569.

${ }^{38}$ On zakāt al-fitr, see further de Zayas, The Law and Philosophy of Zakat, 232-233; al-Qardawi, Fiqh az-Zakat, 538-539. 
listed in Surah 9:60, ${ }^{39}$ and seldom give any further discussion on the qualifications of each of the eight categories or the exact allocation among the various categories. ${ }^{40}$ Although one could, in principle, regard zakat as a transfer of wealth from the rich to the poor, the intention is not the eradication of poverty but the purification of wealth. This has also been noted by Hunwick, who describes zakat as a moral economy of salvation: The spending of one's wealth with the intention to give zakat not only purifies the wealth itself but the giver is promised a reward in heaven, ${ }^{41}$ while Benthall defines it as 'financial worship'. ${ }^{42}$

However, although it is an Islamic imperative to raise the real income of the poor to ensure the maintenance of a minimum level of living, Muslim intellectuals, such as M. A. Mannan, underline, that there is another side of the coin: Assistance can only be given to the 'deserving' poor and not to increase any forms of leisure. ${ }^{43}$ The background for this is that the Qur'an already has identified the poor (miskin) and the needy (faqir) as two of the eight categories of recipients of zakat. However, neither the Qur'an nor the classical legal texts give a precise definition of these two categories, not to speak about the qualifications of the eight categories or the exact allocation among the various categories. The reason for this, it can be argued, might be due to the fact that it is the intention of the giver which is crucial in Islam, not the position of the

${ }^{39}$ The eight categories of recipients of zakat as listed in Sura 9:60 are: the poor (faqir), the destitute (miskin), the collectors of zakat, those slaves who want to ransom themselves, the hard-pressed debtors, for expenditure in God's cause, the wayfarers and those whose hearts have not been reconciled.

${ }^{40} \mathrm{~A}$ detailed outline and discussion of the definitions and conditions of the lawful recipients of zakat are provided by de Zayas, The Law and Philosophy of Zakat, 284-306; Qardawi, Fiqh az-Zakat, 343-437.

${ }^{41}$ John Hunwick, "Islamic Financial Institutions: Theoretical Structures and Aspects of Their Application in Sub-Saharan Africa," in Credit, Currencies and Culture, eds. Endre Stiansen and Jane Guyer (Uppsala: Nordiska Afrikainstitutet, 1999), 72-96.

${ }^{42}$ Jonathan Benthall, "Financial Worship: The Quranic Injunction to Almsgiving," Journal of the Royal Anthropological Institute 5, no. 1 (1999): 27-42. See also Tripp, Islam and the Moral Economy, 124-125.

${ }^{43}$ M.A. Mannan, "The Economics of Poverty in Islam with Special Reference to Muslim Countries," in Distributive Justice and Need Fulfilment in an Islamic Economy, ed. Munawar Iqbal (Islamabad and Leicester: International Institute of Islamic Economics and The Islamic Foundation, 1988), 328. 
receiver. One of the basic virtues is to refrain from asking for assistance. ${ }^{44}$ Miserliness is condemned by the shari'a (Muslim law) and a generous person is considered to be a friend of Allah. However, begging as such is condemned by Islamic Law as an unlawful act itself. Muslims are asked to struggle to earn their lawful livelihood and not merely to depend upon charity except in a situation of extreme necessity. ${ }^{45}$

\section{Communitarian Aspects of Islamic Social Welfare}

Social justice forms the cornerstone of the Islamic economic system, and an elaborate social welfare system is perceived as an integral part of an Islamic economy. Islamic economists have argued that an Islamic social welfare system can, and should, only be financed through legal methods of taxation, in particular through zakat. In theory, as M. N. Siddiqi claims, zakat should be managed by an Islamic state if such a state is ruled by Islamic Law. On the other hand, in a country where Muslims are in a minority or in Muslim states where Islamic Law is not implemented, the role of the state is taken over by voluntary organizations managing zakat. ${ }^{46}$

One reason for the lack of any elaborate rules governing the receiving and the condition of the recipients is due to the communitarian nature of zakat. Zakat was-and still is-primarily collected from and distributed in the same local Muslim community where the imam is supposed to, and usually does, know the rich and the poor members. ${ }^{47}$ The communitarian aspect of zakat has, on the other hand, resulted in a problematic situation for contemporary Muslims living in societies where aspects of social welfare are increasingly tied to the obligations of the state. Most, if not all, Muslim commentators are fully aware of the fact that the way zakat has hitherto been managed in most Muslim societiesthrough informal, unorganized and private channels and within the local

\footnotetext{
${ }^{44}$ Holger Weiss, Obligatory Almsgiving: An Inquiry into Zakât in the Pre-colonial Bilad al-Sûdân (Helsinki: Finnish Oriental Society, 2003), 36-37.

${ }^{45}$ Doi, Sharî'ah, 393-394.

${ }^{46}$ Nejatullah M. Siddiqi, Role of the State in the Economy: An Islamic Perspective (Leicester: The Islamic Foundation, 1996), 129.

${ }^{47}$ Weiss, Obligatory Almsgiving, 37.
} 
community — has had little effect to alleviate modern forms of structural poverty as it is rarely used as seed money or investment. ${ }^{48}$

The effects of neoliberal globalization since the 1990s gave wake to a communitarian approach on existing instruments of Islamic social finance, such as zakat and waqf (pious endowments), as well as generated a vibrant discussion on the introduction of new ones, such as Islamic microfinance. ${ }^{49}$ Zakat is recognized by Muslim experts in Islamic economics as the traditional tool for the eradication of poverty but has in recent decades started to zoom on the potentials of waqf and Islamic microfinance in the provision of maslaba (social welfare). In this discourse, the umma is not anymore equated as merely the community of believers but as (Muslim) society at large. ${ }^{50}$ In the 1990s, as Valeria Saggiomo notes, there was an attempt to arrive at an Islamic notion of sustainable social and economic development based on the principle of social justice. In 1994, Mohamed Ansari proposed an Islamic solution to sustainable development, its main aim being to achieve peace and harmony at all levels of human existence. When Muslim intellectuals turned their attention to what makes it impossible to achieve peace and harmony in the dimensions set out by Ansari, poverty was identified as the prime obstacle to development. ${ }^{51}$ Harvard-trained economists and some economists of the World Bank turned towards Islamic economics and made it more 'fashionable'; the most popular modern manual on Islamic economics is perhaps Yusuf al-Qardawi's Fiqh az-Zakat. Islamic economics has since then been articulated as the solution for an Islamic welfare state policy and has also been discussed among African Muslim scholars. Not surprisingly, the upsurge of Islamic economics in Africa has been closely

\footnotetext{
${ }^{48}$ Nazamul Hoque, Mohammed Aktaruzzaman Khan and Khazi Deen Mohammed, "Poverty Alleviation by Zakah in a Transitional Economy: A Small Business Entrepreneurial Framework," Journal of Global Entrepreneurship Research 5, no. 7 (2015): 14.

${ }^{49}$ World Bank and Islamic Development Bank Group, Global Report on Islamic Finance-Islamic Finance: A Catalyst for Shared Prosperity? (Washington, DC: World Bank Group, 2016), 174-199; Mustapha Abdul-Hamid and Mohammed Fazwi Aminu Amadu, "Islam and Ghana's Sustainable Development Agenda: Negotiating the Involvement of the Muslim Community in Mainstream Economic Activity," in Religion and Sustainable Development: Ghanaian Perspectives, eds. George Ossom-Batsa, Nicoletta Gatti and Rabiatu Deinyo Ammah (Citta del Vaticano: Urbaniana University Press, 2018), 131-144.

${ }^{50}$ Charles Tripp, Islam and the Moral Economy: The Challenge of Capitalism (Cambridge: Cambridge University Press, 2006), 68-76.

${ }^{51}$ Saggiomo, "Islamic NGOs in Africa."
} 
linked, on the one hand, with the politicization of Islam and, on the other hand, to the Islamization of society. ${ }^{52}$ Zakat emerged in these discussions as the foundation of an Islamic social welfare system. In 2007, the World Zakat Forum (WZF) was established in Kuala Lumpur as a platform for governmental and non-governmental zakat organizations. By 2019, the WZF has member organizations in 33 countries, of which nine in sub-Saharan countries (Benin, Ghana, Liberia, Nigeria, Senegal, Sierra Leone, South Africa, Togo and Uganda). ${ }^{53}$ Recently, international non-Muslim organizations have made online calls for zakat and established in 2019 a special funds for these donations, the Refugee Zakat Fund of the United Nations Refugee Agency UNHCR to support refugee and displaced families from Syria, Iraq, Yemen, Myanmar and Mali. ${ }^{54}$

With the crisis of the public sector in many contemporary African states, the Muslim discourse once again gained momentum, including the projection of zakat as the basis of social self-help programme, ${ }^{55}$ as discussed in chapter "Discourses on Zakat and Its Implementation in Contemporary Ghana". Zakat is regarded to be a safety net to take care of the basic necessities of life of those who cannot afford them. According to the traditional interpretation of Muslim scholars, zakat funds cannot be used to finance infrastructure projects, public utilities and services beneficial to all Muslims. Some Muslim scholars therefore argue that zakat should first and foremost be used as seed money for economic empowerment of the poor and needy. ${ }^{56}$ However, it has become painfully evident that the original legal model of Islamic taxation has become difficult to apply in postcolonial Muslim states. ${ }^{57}$

\footnotetext{
${ }^{52}$ Benthall, Islamic Charities; Petersen, For Humanity or for the Umma?, 28-29.

${ }^{53}$ See further http://worldzakatforum.org.

${ }^{54}$ https://www.unhcr.org/hk/en/21723-unhcr-unveils-the-refugee-zakat-fund-a-global-islamic-finance-structure-to-help-displaced-populations-worldwide.html.

${ }^{55}$ Yusuff Jelili Amuda, "Empowerment of Nigerian Muslim Households Through Waqf, Zakat and Public Funding," International Journal of Economics and Finance 4, no. 6 (December 2013): 419-424.

${ }^{56}$ Hoque, Khan and Mohammed, "Poverty Alleviation by Zakah in a Transitional Economy."

${ }^{57}$ Benthall, "Financial Worship"; Isahaque Ali and Zulkarnain A. Hatta, "Zakat as a Poverty Reduction Mechanism Among the Muslim Community: Case Study of Bangladesh, Malaysia and Indonesia," Asian Social Work and Policy Review 8 (2014): 59-70; Kazi Sohag et al., "Can Zakat System Alleviate Rural Poverty in Bangladesh? A Propensity Score Matching Approach," Journal of Poverty 19, no. 3 (2015): 261-277;
} 
In some Muslim countries, government attempts to dominate and regulate zakat have been met with widespread resistance. Far from signalling the de-politicization of Islamism, informal zakat, reclaimed from the state, explicitly critiques the nation-state at the level of corruption, failure and illegitimacy and responds to contemporary political crisis in contradistinction to the logic of the nation-state framework..$^{58}$

One problem is that Islamic principles such as zakat are often applied within structures which are essentially non-Islamic. While Muslim scholars have debated the ways in which zakat may be interpreted as a form of taxation appropriate to a modern state, or the power of an Islamic state to raise taxes over and above zakat, zakat tends in practice to remain as a parallel or supplementary channel of revenue raising and distribution. ${ }^{59}$ Kuran is even more critical about the feasibility of Islamic economics, not to speak about a modern social welfare system based on zakat, and has in his research refuted the claim of modern Islamists that zakat has the capacity to reduce inequality and evolve as an agent of massive equalization rather than serving as an instrument for wealth legitimization and political stabilization. ${ }^{60}$ According to him, the doctrine of Islamic economics is simplistic, incoherent and largely irrelevant to present economic challenges. In his view, the purpose of Islamic economics has not been economic improvement but cultivation of a distinct Islamic identity to resist cultural globalization. His conclusion is that the various

Dominik M. Müller, "From Consultancy to Critique: The 'Success Story' of Globalized Zakat Management in Malysia and Its Normative Ambiguities," Globalizations 14, no. 1 (2016): 81-98; Muhamed Zulkhibri, "Financial Inclusion, Financial Inclusion Policy and Islamic Finance," Macroeconomics and Finance in Emerging Market Economies 9, no. 3 (2016): 303-320.

${ }^{58}$ Samantha May, "Political Piety: The Politicization of Zakat," Middle East Critique 22, no. 2 (2013): 149-164.

${ }^{59}$ Hartley Dean and Zafar Khan, "Muslim Perspectives on Welfare," Journal of Social Policy 26, no. 2 (1997): 203.

${ }^{60}$ Timur Kuran, "Islamic Redistribution Through Zakat: Historical Record and Modern Realities," in Poverty and Charity in Middle Eastern Contexts, eds. Michael Bonner, Mime Ener and Amy Singer (Albany, NY: State University of New York Press, 2003), 275-293; Timur Kuran, Zakat: Islam's Missed Opportunity to Limit Predatory Taxation, Economic Research Initiatives at Duke (ERID) Working Paper No. 284, 8 April 2019, available at https://papers.ssrn.com/sol3/papers.cfm?abstract_id=3368292 (checked 6 August 2019). 
Islamic sub-economies that have sprung up across the Islamic world are not manifestations of Islamic economics but the aspirations of socially marginalized groups. ${ }^{61}$ Further, Shirazi, Ali and Obaidullah critically note that although Muslims in OIC countries are paying zakat, these transactions are in most countries not passing through proper channels, are un-recorded and are not a part of any strategy. Therefore, its effect on poverty alleviation is difficult to assess. ${ }^{62}$

Contemporary Muslim economists have started to call for a shift to other instruments of Islamic social finance, including waqf and Islamic microfinance, as effective tools for poverty alleviation. ${ }^{63}$ Recognizing the inflexibility and limitations of zakat, they present waqf as an Islamic open-ended pooling system to achieve structural changes and to meet the UN Sustainable Development Goals. ${ }^{64}$ In addition, other instruments of Islamic social finance, most importantly Islamic banking, Islamic bonds (sukuk), Islamic cooperative insurance (takaful), Islamic micro-finance institutions and Islamic crowd-funding, are identified as

${ }^{61}$ Timur Kuran, Islam and Mammon: The Economic Predicaments of Islamism (Princeton, NJ: Princeton University Press, 2004).

${ }^{62}$ Nasim Shah Shirazi, Salman Syed Ali and Mohammed Obaidullah, "Practical Means of Integrating Zakāt and Waqf Into Poverty Reduction Agenda of OIC Member Countries," Islamic Economic Studies 25, no. 2 (2017): 65.

${ }^{63}$ Mohamed Aslam Haneef et al., "Integration of Waqf-Islamic Microfinance Model for Poverty Reduction: The Case of Bangladesh," International Journal of Islamic and Middle Eastern Finance and Management 8, no. 2 (2015), 246-270; Niaz Ahmed Khan and Sultana Jareen, "The Waqf and Human Security in Muslim Majority Countries: Traditions, Modern Practices, and Challenges," in Human Security and Philanthropy: Islamic Perspectives and Muslim Majority Country Practices, ed. Samiul Hasan (New York: Springer, 2015), 183-204; Fatima Rasheed, "Microfinance Institutions and Human Security in Muslim Majority Countries: Achievements and Challenges," in Human Security and Philanthropy: Islamic Perspectives and Muslim Majority Country Practices, ed. Samiul Hasan (New York: Springer, 2015), 205-230.

${ }^{64}$ Nur Atikah Atan and Fuadah Binti Johari, "A Review on Literature of Waqf for Poverty Alleviation Between 2006-2016," Library Philosophy and Practice 1486 (e-journal; June 2017) http://digitalcommons.unl.edu/libphilprac/1486 (checked 26 March 2019); Abubakar Yusuf Sanyinna and Muhammad Farihal Osman, "Analytical Overview of the Role Played by Waqf in Poverty Alleviation: A Case Study of Sokoto State, Nigeria," Asian Journal of Multidisciplinary Studies 5, no. 9 (2017): 18-30. On waqf and Sustainable Development Goals, see further Mohammad Abdullah, "Waqf, Sustainable Development Goals (SDGs) and maqasid al-shariah," International Journal of Social Economics 45, no. 1 (2018): 158-172. 
key instruments for financing the Sustainable Development Goals. Not least, as a 2017 joint UNDP, Istanbul International Center for Private Sector Development and Islamic Research and Training Institute Report realizes that the market for Islamic financial services is projected to grow from USD 200 billion in 2003 to USD 2.7 trillion in 2021, while its global assets are expected to surpass USD 3 trillion by 2020. Although Islamic financial services are of systematic importance in four countries, Iran, Malaysia, Saudi Arabia and Sudan, and a potential one in the Gulf States, Indonesia, Pakistan and Turkey, the 2017 Report also recognizes the growth of such services in several sub-Saharan African countries. ${ }^{65}$

\section{Muslim NGOs and ZaKat in Sub-Saharan Africa}

The question of an Islamic social welfare system based upon zakat is even more complicated-if not impossible-in states where Muslims are a minority or the state is a secular one which is the case in many sub-Saharan African countries. In many places in sub-Saharan Africa, the local mosque has been and continues to be the principal institution for collecting and distributing zakat. ${ }^{66}$ Last and Soares have introduced the term 'prayer economics' in describing the complex practices among Muslim societies and enclaves in West Africa where considerable sums are given to Muslim scholars for prayers, blessings and Islamic

${ }^{65}$ United Nations Development Programme, Istanbul International Center for Private Sector Development and Islamic Research and Training Institute, I For Impact: Blending Islamic Finance and Investing for the Global Goals, March 2017, http://www.irti.org/ English/News/Documents/IRTI_UN_Islamic_Financial_Report.pdf (checked 6 August 2019).

${ }^{66}$ David E. Skinner, "Da'wa and Politics in West Africa: Muslim Jama'at and NonGovernmental Organisations in Ghana, Sierra Leone and The Gambia," in Development and Politics from Below: Exploring Religious Spaces in the African State, eds. Barbara Bompai and Maria Frahm-Arp (London: Palgrave Macmillan, 2010), 99-130. Also ILO, "Annex B: Situational Analysis on Zakat and Other Religious Provision in Zanzibar," in International Labour Office, Social Security Department, Zanzibar: Social Protection Expenditure and Performance Review and Social Budget (Geneva: ILO, 2010), 209-220; Mukerrem Miftah, "Poverty and Zakat: The Feasibility of Institutionally Administering Zakat in Ethiopia," in 3rd International ILEM Summer School 2015: Social Justice and Poverty in Muslim World, Proceedings, 235-244, downloaded from https://www.academia.edu/14607354/The_Practice_of_Zakat_Among_Muslim_Ethiopians_ILEM_ Proceedings_2015 (6.8.2019). 
medicine. ${ }^{67}$ Soares further describes the prayer economy as operating through the circulation of capital-economic, political and spiritual or symbolic - which particular social actors are able to convert from one domain to another. ${ }^{68}$ According to him, the prayer economy is, in effect, an economy of religious practice in which people give gifts to certain religious leaders on a large scale in exchange for prayers and blessings. In his view, the exchange of blessings and prayers for commodities has resulted in a process of commodification which has proliferated and intensified around such religious leaders in the postcolonial period. Such processes of commodification have helped to transform the relations between religious leaders and followers and have resulted in a religious economy that has come to be more like a market. ${ }^{69}$

As noted above, Muslim faith-based NGOs have become an increasingly popular avenue for zakat collection and distribution some sub-Saharan countries since the late twentieth century. This development reflects the situation of the Muslim communities in non-Muslim countries: Since there is no governmental or state engagement in the collection and supervision of zakat, the collection and distribution of zakat becomes a private matter or, as in the case of South Africa, Zimbabwe, Malawi, Tanzania (including Zanzibar) and Kenya, is organized by Muslim faith-based NGOs, see Table $1 .^{70}$

${ }^{67}$ Murray Last, "Charisma and Medicine in Northern Nigeria," in Charisma and Brotherhood in African Islam, eds. D. B. Cruise O'Brien and C. Coulon (Oxford: Clarendon Press, 1988), 183-204; Benjamin F. Soares, "The Prayer Economy in a Malian Town," Cahiers d'Études africaines 36, no. 4 (1996): 739-754.

${ }^{68}$ Soares, "The Prayer Economy," 741.

${ }^{69}$ Benjamin F. Soares, Islam and the Prayer Economy: History and Authority in a Malian Town (Edinburgh: Edinburgh University Press for the International Africa Institute, 2005), 153, 171-179.

${ }^{70}$ Weiss, Begging and Almsgiving in Ghana; Nabila Saddiq, Capacity Building and Islamic NGOs: Insights from Malawi, INTRAC Praxis Note 48 (2009), https://www. intrac.org/wpcms/wp-content/uploads/2016/09/Praxis-Note-48-Capacity-Building-andIslamic-NGOs-Nabila-Saddiq.pdf; Justin Pierce, "The Role and Governance of Islamic Faith Organisations in South Africa," in Charities in the Non-Western World: The Development and Regulation of Indigenous and Islamic Charities, eds. Rajeswary Ampalawar Brown and Justin Pierce (Abingdon, Oxon and New York: Routledge 2013), 40-64; Robert Leurs, Peter Tumaini-Mungu and Abu Mvungi, Mapping the Development Activities of Faith-Based Organizations in Tanzania, Religions and Development Research Programme Working Paper 58 (Birmingham: International Development Department, University of Birmingham, 2011); Khatib Mjaka Mkuu and Mohd Effandi Bin Yusoff, "Zakat Institution: 
Table 1 Zakat collecting and distributing Muslim faith-based NGOs in subSaharan Africa

\begin{tabular}{|c|c|c|c|}
\hline Organization & Abbreviation & Establishment & Followers on Facebook \\
\hline $\begin{array}{l}\text { South African National Zakat } \\
\text { Fund }\end{array}$ & ZANZAF & 1974 & 6242 \\
\hline $\begin{array}{l}\text { Zanzibar Waqf and Trust } \\
\text { Commission }\end{array}$ & ZWTC & 1980 & {$[\ldots]$} \\
\hline $\begin{array}{l}\text { Conselho Islâmico de } \\
\text { Mocambique }\end{array}$ & CISLAMO & 1981 & 3506 \\
\hline Malawi Islamic Zakaat Fund & $\mathrm{IZF}$ & 1991 & 2504 \\
\hline $\begin{array}{l}\text { Zakat and Sadaqat Foundation } \\
\text { (Lagos State, Nigeria) }\end{array}$ & ZSF & 2000 & 5563 \\
\hline $\begin{array}{l}\text { Waqf and Trust Commission } \\
\text { of Zanzibar }\end{array}$ & WTC & {$[1905] 2007$} & {$[\ldots]$} \\
\hline Fonds Sénégalais pour la Zakat & & 2009 & 4904 \\
\hline $\begin{array}{l}\text { House of Zakat and Waqf } \\
\text { (Uganda) }\end{array}$ & HZWU & 2010 & 21,723 \\
\hline $\begin{array}{l}\text { Fondation Zakat et Waqf } \\
\text { (La Côte d'Ivoire) }\end{array}$ & & 2010 & 63 \\
\hline $\begin{array}{l}\text { Zakat and Sadaqa Fund of } \\
\text { Ghana }\end{array}$ & ZSFG & 2010 & 3064 \\
\hline $\begin{array}{l}\text { Zimbabwe National Zakat } \\
\text { Fund }\end{array}$ & ZIMNZAF & $?$ & 43 \\
\hline Taasisi ya Zaka Tanzania & Tauzakati & $?$ & {$[\ldots]$} \\
\hline $\begin{array}{l}\text { Lindi Islamic Foundation } \\
\text { of Tanzania }\end{array}$ & LIFT & 2013 & {$[\ldots]$} \\
\hline $\begin{array}{l}\text { National Zakat } \\
\text { Foundation-Kenya }\end{array}$ & $\mathrm{NZF}$ & $?$ & 2173 \\
\hline
\end{tabular}

Source Facebook and homepages of selected organizations; date of retrieval: 8 August 2019

The number of followers on Facebook gives a hint on the support that a zakat-managing Muslim faith-based NGO attracts. However, the figures displayed in Table 1 do not tell whether the followers are local or foreign ones, for example South African or Ghanaian Muslim living abroad. Also, the figures reflect the response Muslim faith-based NGOs

An Alternative for Poverty Alleviation in Zanzibar," European Journal of Business and Management 9, no. 14 (2017): 57-63. The Zimbabwe National Zakat Fund has no homepage, only a Facebook account with very limited information, see https://www.facebook. com/zimnzaf/. 
have received by presumably younger Muslims actively engaged in cyberspace. Elder Muslims who are not active on the Internet would not respond but are likely to be those who pay zakat. Also, further research is needed, especially on zakat-managing organizations in Francophone sub-Saharan Africa. Nevertheless, some tentative conclusions can be drawn. Active organizations with thousands of followers are found in Southern Africa (South Africa, Mozambique, Malawi), Eastern Africa (Uganda) and Western Africa (Nigeria, Senegal, Ghana). The Ugandan House of Zakat and Waqf, especially, has been recognized for its national impact by the World Zakat Forum. ${ }^{71}$ The Kenyan National Zakat Foundation concentrates its activities in the Nairobi metropolitan area and is present on the Internet via blogspot, Facebook (2137 followers as per 25 September 2019) and runs a new homepage since 2019. ${ }^{72}$ The Lindi Islamic Foundation of Tanzania is an example of a local Muslim faith-based NGO that directs its call for zakat donations both to local Muslims and to expatriate communities in the USA. ${ }^{73}$ In Zanzibar, the Waqf and Trust Commission Zanzibar is a governmental body entrusted in the supervision and management of zakat (zakka) since its reorganization in $2007 .{ }^{74}$ It established a zakat diwan in $2011^{75}$ and has since

71 "House of Zakat and Waqf Uganda Holds The 1st National Zakat Conference," 20 April 2019, https://worldzakatforum.org/index.php/africa/56-africa/209-house-ofzakat-and-waqf-uganda-holds-the-1st-national-zakat-conference (checked 6 August 2019); "House of Zakat and Waqf Uganda Gives Shs 1,164,908,300 (USD 309,816), to Poor and Needy," 2 July 2019, https://worldzakatforum.org/africa/56-africa/210-house-ofzakat-and-waqf-uganda-gives-shs1-164-908-300-usd-309-816-to-poor-and-needy.html (checked 6 August 2019).

${ }^{72}$ https://thenationalzakatfoundation.blogspot.com and https://www.facebook.com/ Zakatke/. See further the homepage of the Fund, http://www.zakat.co.ke.

${ }^{73}$ Lindi Islamic Foundation of Tanzania, “Our Programs," http://tanzania-lift.org/ index.php/our-programs/ (checked 31 December 2019).

${ }^{74}$ See The Waqf and Trust Commission Act No. 2 of 2007 , available as PDF on http://www.wakf.go.tz/assets/img/documents/WAKF\%20AND\%20TRUST\%20 COMMISSION\%20ACT,\%202007.pdf. Also Issa Haji Ziddy, "Review of the Waqf and Trust Commission (WTC) in Zanzibar," Inquiry: Sarajevo Journal of Social Sciences 1 (2015): 29-45.

${ }^{75}$ See further "Muongozo wa Shuguli za Zakka Zanzibar" (http://www.wakf.go.tz/ assets/img/documents/MUONGOZO\%20WA\%20ZAKKA\%20ZANZIBAR.pdf) as well as "An Important Tool for the Welfare of Zanzibaris" (http://www.wakf.go.tz/assets/img/ documents/AN\%20IMPORTANT\%20TOOL\%20FOR\%20THE\%20WELFARE\%20OF\%20 ZANZIBARIS.pdf). 
then established detailed structures and channels for its collection and distribution as well as for the calculation of nisab. ${ }^{76}$

The Nigerian case is an interesting one, too. Whereas the Zakat and Sadaqat Foundation is a Muslim faith-based organization based in Lagos, ${ }^{77}$ all zakat-managing organizations in the northern, predominantly Muslim states are state or governmental organizations. Until 2003, when Zamfara State was the first to establish a government-controlled institution, the Zamfara State Zakat and Endowment Board, ${ }^{78}$ the only zakat body in Nigeria was the 1982-established non-governmental Kano State Council for Zakat. ${ }^{79}$ In the wake of the implementation of Shari'a, zakat boards and commissions have been established in twelve northern states in Nigeria. ${ }^{80}$ Nevertheless, as the payment of zakat to state commissions is not compulsory according to law as well as due to the ineffectiveness and poor management of the government authorities, the performance of these institutions has been generally low. There is little trust in these institutions, and many Muslims still prefer to pay their zakat directly to needy beneficiaries in their community instead of handling it to the zakat collecting authorities. Also, Muslim faith-based organizations, such as the Yan Izala, challenge the monopoly of the state as the collector and distributor of zakat and have established their own zakat units. ${ }^{81}$ The gender dimension,

\footnotetext{
${ }^{76}$ See further http://www.wakf.go.tz/zakkat.php and http://www.wakf.go.tz/zakkatdetails.php.

${ }^{77}$ https://zakatandsadaqat.org.ng.

${ }^{78}$ http://zakatzamfara.org.

${ }^{79}$ Sheriff Ibrahim Muhammad and Aliyu Muhammad Dahiru, "In Search of an Effective Zakat Distribution System in Kano State Nigeria," Journal for Studies in Management and Planning 1, no. 7 (2015): 345-368.

${ }^{80}$ Bauchi, Borno, Gombe, Jigawa, Kaduna, Kano, Katsina, Kebbi, Niger, Sokoto, Yobe, and Zamfara State. For detailed information on the introduction and implementation of zakat in the twelve states, see Philip Ostien, comp. and ed., Sharia Implementation in Northern Nigeria 1999-2006: A Sourcebook, Further Documentary Materials III: Zakat and Endowment Boards and Committees (Ibadan: Spectrum Books 2007), available with updates on https://beta.shariasource.com/documents/3338. See further Dauda Abubakar, "The Institutionalization of Zakat in the Shari'a States of Northern Nigeria," Journal Foundation of African Theology 1, no. 5 (2015): 76-92.

${ }^{81}$ Dauda Abubakar, "The Giving and Receiving of Zakât: Anthropological Analysis of Relationship Between the 'Wealthy' and 'Needy' Citizens in Jos, Nigeria," International Journal of Humanities and Social Science 3, no. 9 (2013): 121-131; Dauda Abubakar,
} 
too, is critically addressed by some authors as Muslim women's non-governmental and civil society organizations active in the provision of social welfare do not in general receive any support from the zakat commissions. ${ }^{82}$

The United Nations Development Programme identifies Islamic social finance tools such as zakat, sadaqa and waqf as highly aligned with the spirit of the Sustainable Development Goals. ${ }^{83}$ The potential resources and impact of Islamic social finance instruments, notably zakat, varies greatly in sub-Saharan Africa countries according to the 2016 World Bank/Islamic Development Bank Report. The Report establishes three figures for calculating the potential resource basis of zakat in South Africa, Tanzania, Kenya, Sudan and Nigeria. The first one, Zl, is estimated in accordance with the majority traditional view according to which zakat is levied on agriculture, livestock, stock-in-trade, gold, silver and money. The second one, $\mathrm{Z2}$, is based on the view of some contemporary Muslim scholars that zakat is payable on net returns of manufacturing concerns, rentals of building, and net savings out of salaries. The third one, Z3, is based on views of the Maliki School, in which the zakat base includes buildings and other fixed assets, except those assigned for personal and family use. Further, the GDP of each country was adjusted by taking into account per capita income and the proportion of Muslim population in each country. The potential of zakat in the five countries

"The Practice of Zakât in Northern Nigeria and the Building of Social Relationships," in Charity in Jewish, Christian, and Islamic Traditions, eds. Julia R. Lieberman and Michal Jan Rozbicki (Lanham, ML: Lexington Books, 2017), 204-207; Abubakar U. Farouk, Kamil Md Idris and Ram Al Jaffri Saad, "Determinants of Attitude Towards Zakat on Employment Income in Nigeria," The International Journal of Banking and Finance 13, no. 1 (2017): 29-48; Abubakar U. Farouk, Kamil B Md Idris and Ram Al Jaffri B Saad, "The Challenges of Zakat Management: A Case of Kano State, Nigeria," Asian Journal of Multidisciplinary Studies 5, no. 7 (2017): 142-147; Mahadi Ahmad, "An Empirical Study of the Challenges Facing Zakat and Waqf Institutions in Northern Nigeria," ISRA International Journal of Islamic Finance (2019), https://doi.org/10.1108/IJIF-04-20180044 (publication date: 11 November 2019).

${ }^{82}$ Adryan Wallace, “Agency Through Development: Hausa Women's NGOs and CBOs in Kano, Nigeria," Feminist Economics 20, no. 4 (2014): 287-288.

${ }^{83}$ United Nations Development Programme "Islamic Finance Partners," https://www. undp.org/content/undp/en/home/partners/islamic-finance.html (checked 6 August 2019). 
Table 2 Estimates of the potential of zakat (\% of GDP)

\begin{tabular}{lccc}
\hline Country & $Z 1$ & $Z 2$ & $Z 3$ \\
\hline Kenya & 0.13 & 0.27 & 0.30 \\
Nigeria & 0.86 & 1.84 & 2.08 \\
South Africa & 0.03 & 0.06 & 0.07 \\
Sudan & 1.44 & 3.08 & 3.47 \\
Tanzania & 0.54 & 1.15 & 1.30 \\
\hline
\end{tabular}

Source World Bank and Islamic Development Bank Group, Global Report on Islamic Finance-Islamic Finance: A Catalyst for Shared Prosperity? [Washington, DC: World Bank Group, 2016], Fig. 9.2

is summarized in Table 2. These figures are contrasted with the gap in resources needed to alleviate poverty, as presented in Table $3 .{ }^{84}$

The 2016 World Bank/Islamic Development Bank Report highlights that countries like Kenya, Nigeria, South Africa and Sudan can easily generate resources for poverty alleviation. On the other hand, Tanzania would be unable to bridge the resource gap with potential zakat collection. Nevertheless, the mobilization of zakat resources falls short of its potential in most countries. In Nigeria, total zakat collected was USD 3 million in 2013, but it has fluctuated greatly. The Nigerian figures, the Report notes, fall behind those collected in Indonesia (USD 231.6 million/2012), Malaysia (USD 628.6 million/2013), Pakistan (USD 20.4 million/2012) and the Sudan (USD 220 million/2013). ${ }^{85}$ An earlier report by the Islamic Research and Training Institute, which findings and data were used by the 2016 World Bank/Islamic Development Bank Report, disappointedly remarked that there seemed to be a total lack of awareness among the public on zakat in Mozambique, and neither in Tanzania nor in Kenya was there an organized effort to managed

\footnotetext{
${ }^{84}$ World Bank and Islamic Development Bank Group, Global Report on Islamic Finance, 185-186. See further Islamic Research and Training Institute, Islamic Social Finance Report, 15 June 2015, http://www.irti.org/English/Research/Documents/IDB\%20 GLOBAL\%20FORUM\%20ON\%20ISLAMIC\%20FINANCE/10th_Global_Forum / Islamic\%20Social\%20Finance\%20Report.pdf (checked 6 August 2019); Salman Ahmed Shaikh and Qazi Masood Ahmed, "Estimation of Potential Zakat in OIC," in Social Justice and Islamic Economics: Theory, Issues and Practice, eds. Toseef Azid and Lufti Sunar (Abingdon and New York: Routledge, 2019).

${ }^{85}$ World Bank and Islamic Development Bank Group, Global Report on Islamic Finance, 186-189.
} 
Table 3 Gap in resources needed to alleviate poverty

\begin{tabular}{lcc}
\hline Country & $\begin{array}{c}\text { Resource gap at USD 1.25 a day } \\
\text { (\% of GDP) }\end{array}$ & $\begin{array}{c}\text { Resource gap at USD 2.00 a day } \\
\text { (\% of GDP) }\end{array}$ \\
\hline Kenya & 0.320 & 0.96 \\
Nigeria & 1.470 & 3.50 \\
South Africa & 0.001 & 0.01 \\
Sudan & 0.490 & 2.20 \\
Tanzania & 3.020 & 8.17 \\
\hline
\end{tabular}

Source World Bank and Islamic Development Bank Group, Global Report on Islamic Finance-Islamic Finance: A Catalyst for Shared Prosperity? [Washington, DC: World Bank Group, 2016], Fig. 9.1

its collection and distribution. ${ }^{86}$ Similar critical conclusions were reached by Shaikh in his calculation of the estimated and potential value of zakat in OIC countries. Although the estimated value of zakat as percentage of Nigerian Gross Domestic Product in 2013 was 2.20\%, the potential collectible zakat was calculated by him as high as 11,460 million USD. Still, the collected sum was estimated by him to have targeted some 25 million Nigerians. ${ }^{87}$ However, as Wali notes, given that 12 million live in the northern Kano State alone, zakat and other forms of Islamic social investment have not been sufficient to alleviate poverty. ${ }^{88}$

A total different situation prevails in South Africa where Muslims constitute a small minority. Here, the performance of the South African Zakat Fund has been excellent with about USD 13 million being collected in 2013. Not surprisingly, the Fund is recognized for having the

\footnotetext{
${ }^{86}$ Islamic Research and Training Institute, Islamic Social Finance Report.
}

${ }^{87}$ S.A. Shaikh, "Zakat Collectible in OIC Countries for Poverty Alleviation: A Primer on Empirical Estimation," International Journal of Zakat 1, no. 1 (2016): 27, 29-30.

${ }^{88}$ H.N. Wali, "Utilization of Zakat and Islamic Endowment Funds for Poverty Reduction: A Case Study of Zakat and Hubsi Commission, Kano State - Nigeria," Journal of Economics and Sustainable Development 4, no. 18 (2013): 141-147. See further "Zakat Management in Nigeria: The Status Quo," New York Essays, 26 September 2016, https://newyorkessays.com/essay-zakat-management-in-nigeria-the-status-quo (checked 6 August 2019); Usman Bugaje and Danladi Ali, The Administration of Zakat and Management of Waqf in the Sharia Implementing States 1999-2015. Report for NRSP/ dRPC/NRN Research Project on Sharia Implementation Over 15 Years. Nigeria Stability and Reconciliation Programme, Sharia Implementation in Northern Nigeria Over 15 Years. Policy Brief No. 3. Zakat \& Waqf (Abuja: British Council, 2016). 
potential to empower Muslims in South Africa. ${ }^{89}$ The South African National Zakat Fund (SANZAF) was established in $1974 .{ }^{90}$ SANZAF defines itself as a 'pro-active, faith-based, socio-welfare and educational organisation'. Its main field of operations is community-based welfare and development, education projects and scholarship programmes as well as emergency relief, food aid and shelter for the needy. ${ }^{91}$ The Fund is one of the most effective Muslim faith-based NGOs in Africa with a keen interest to promote the transparency of its activities as a way of generating trust among its donors and beneficiaries. Since 2014, the Annual Reports are published on its homepage. ${ }^{92}$ SANZAF is a formal and institutionalized philanthropic institution and is registered as a Public Benefit Organisation $(\mathrm{PBO})$. Being a registered $\mathrm{PBO}$, any donation in cash or kind for public benefit activities within South Africa can be claimed as an income tax deduction by the donor. The donation has to be supported by a receipt from SANZAF if the donor wants to claim the tax reduction. ${ }^{93}$ SANZAF's recent project introduces online collection of zakat as to attract a new generation of donors or, as Morton declares: 'SANZAF will find its donors of tomorrow determining their payments online on their hand-held devices, whilst they scroll daily through music, news, Qur'an, Hadith and the issues of the day. In other words, Zakah - like so many other things - will become a cyber-experience'. ${ }^{94}$

Last, but not least, a general assessment of zakat as instrument for poverty alleviation and pro-poor economic development in Muslim communities in sub-Saharan Africa countries is still lacking. Muslim economists estimate that the majority of zakat is privately distributed throughout the Muslim world which undermines its impact on poverty alleviation. Consequently, they call for an institutionalization of zakat, either in the form of greater coordination among institutions-NGOs/

\footnotetext{
${ }^{89}$ World Bank and Islamic Development Bank Group, Global Report on Islamic Finance, 186-189.

${ }^{90}$ Gorkeh Gamal Nkrumah, "Islam in Southern Africa," Review of African Political Economy 52 (1991): 94-97.

${ }^{91}$ https://sanzaf.org.za/about-us.html.

${ }^{92}$ See https://sanzaf.org.za.

${ }^{93}$ https://sanzaf.org.za/about-us.html.

${ }^{94}$ Shafiq Morton, "SANZAF: Travelling into the cyber future," 9 January 2019, https:// sanzaf.org.za/what-we-do/blog/321-sanzaf-travelling-into-the-cyber-future.html (checked 9 July 2019).
} 
CSOs-or even a centralized collection by a public agency. The latter one should in Muslim majority countries be under state control or under the community in Muslim minority countries. However, there is no consensus among Muslim scholars on this issue, as noted by Ismail in her overview and by Weiss in his chapter on the discourse on zakat in Ghana. Conservative Islamist groups and conservative Muslims scholars support state-driven zakat collection instead of voluntary models and reject the idea of Muslim faith-based NGOs collecting and distribution zakat. On the other hand, the experience of state-controlled or centralized collection of zakat is not generally positive. In many OIC countries, including Nigeria, the public has little trust in the government and the state-controlled zakat funds are criticized for mismanagement, malfunction and corruption. Both public and voluntary zakat organizations have further been criticized for a lack of accountability and transparency. ${ }^{95}$

\section{BIBLIOGRAPHY}

Abdalla, Salma Mohamed Abdalmumin. Charity Drops: Water Provision and the Politics of the Zakat Chamber in Khartoum, Sudan. Berlin: Lit Verlag, 2017.

Abdul-Hamid, Mustapha and Mohammed Fazwi Aminu Amadu. "Islam and Ghana's Sustainable Development Agenda: Negotiating the Involvement of the Muslim Community in Mainstream Economic Activity." In Religion and Sustainable Development: Ghanaian Perspectives, eds. George Ossom-Batsa, Nicoletta Gatti and Rabiatu Deinyo Ammah, 131-144. Citta del Vaticano: Urbaniana University Press, 2018.

Abdullah, Mohammad. "Waqf, Sustainable Development Goals (SDGs) and maqasid al-shariah." International Journal of Social Economics 45, no. I (2018): 158-172.

Abubakar, Dauda. "The Giving and Receiving of Zakât. Anthropological Analysis of Relationship Between the 'Wealthy' and 'Needy' Citizens in Jos, Nigeria." International Journal of Humanities and Social Science 3, no. 9 (2013): 121-131.

Abubakar, Dauda. "The Institutionalization of Zakat in the Shari'a States of Northern Nigeria." Journal Foundation of African Theology 1, no. 5 (2015): 76-92.

Abubakar, Dauda. "The Practice of Zakât in Northern Nigeria and the Building of Social Relationships." In Charity in Jewish, Christian, and Islamic

${ }^{95}$ See further Ismail, Using Zakat for International Development, 6-7. 
Traditions, eds. Julia R. Lieberman and Michal Jan Rozbicki, 195-210. Lanham, ML: Lexington Books, 2017.

Ahmad, Mahadi. "An Empirical Study of the Challenges Facing Zakat and Waqf Institutions in Northern Nigeria." ISRA International Journal of Islamic Finance (2019). https://doi.org/10.1108/IJIF-04-2018-0044 (publication date: 11 November 2019).

Ahmed, Chanfi. "Networks of Islamic NGOs in Sub-Saharan Africa: Bilal Muslim Mission, African Muslim Agency (Direct Aid), and al-Haramayn." Journal of Eastern African Studies 3, no. 3 (2009): 426-437.

Ali, Isahaque and Zulkarnain A. Hatta. "Zakat as a Poverty Reduction Mechanism Among the Muslim Community: Case Study of Bangladesh, Malaysia and Indonesia." Asian Social Work and Policy Review 8 (2014): 59-70.

Amuda, Yusuff Jelili. "Empowerment of Nigerian Muslim Households Through Waqf, Zakat and Public Funding." International Journal of Economics and Finance 4, no. 6 (December 2013): 419-424.

Atan, Nur Atikah and Fuadah Binti Johari. "A Review on Literature of Waqf for Poverty Alleviation Between 2006-2016." Library Philosophy and Practice 1486 (e-journal; June 2017) http://digitalcommons.unl.edu/libphilprac/1486 (checked 26 March 2019).

Benedetti, Carlo. "Islamic and Christian Inspired Relief NGOs: Between Tactical Collaboration and Strategic Difference?" Journal of International Development 18 (2006): 849-859.

Benthall, Jonathan. "Financial Worship: The Quranic Injunction to Almsgiving." Journal of the Royal Anthropological Institute 5, no. 1 (1999): 27-42.

Benthall, Jonathan. Islamic Charities and Islamic Humanism in Troubled Times. Manchester: Manchester University Press, 2016.

Bugaje, Usman and Danladi Ali. The Administration of Zakat and Management of Waqf in the Sharia Implementing States 1999-2015. Report for NRSP/ dRPC/NRN Research Project on Sharia Implementation Over 15 Years. Nigeria Stability and Reconciliation Programme, Sharia Implementation in Northern Nigeria Over 15 Years. Policy Brief No. 3. Zakat \& Waqf. Abuja: British Council, 2016.

Burr, J. Millard and Robert O. Collis. Alms for Jihad: Charity and Terrorism in the Islamic World. Cambridge: Cambridge University Press, 2006.

Chapra, M.U. The Islamic Vision of Development. Jeddah: Islamic Research and Training Institute, Islamic Development Bank, 2008.

Chesworth, John A. and Franz Kogelmann, eds. Sharî‘ in Africa Today: Reactions and Responses. Leiden and Boston: Brill, 2013.

Clarke, Gerard. "Faith Matters: Faith-Based Organisations, Civil Society and International Development." Journal of International Development 18 (2006): 835-848. 
Clarke, Gerard. "Faith-Based Organisations and International Development: An Overview." In Development, Civil Society and Faith-Based Organisations: Bridging the Sacred and the Secular, eds. Gerard Clarke and Michael Jennings, 17-45. Basingstoke and New York: Palgrave Macmillan, 2008.

Dean, Hartley and Zafar Khan. "Muslim Perspectives on Welfare." Journal of Social Policy 26, no. 2 (1997): 193-209.

Dibie, Robert A., ed. Non-Governmental Organizations (NGOs) and Sustainable Development in Sub-Sabaran Africa. Lanham: Rowman \& Littlefield, 2008.

Doi, 'Abdur Rahman I. Sharî'ah: The Islamic Law. London: Ta-Ha Publishers, 1984.

Enabling Environment of Philanthropy in Ghana. Accra: SDG Philanthropy Platform, United Nations Development Programme, 2017.

Farouk, Abubakar U., Kamil Md Idris and Ram Al Jaffri Saad. "Determinants of Attitude Towards Zakat on Employment Income in Nigeria." The International Journal of Banking and Finance 13, no. 1 (2017): 29-48.

Farouk, Abubakar U., Kamil B Md Idris and Ram Al Jaffri B Saad. "The Challenges of Zakat Management: A Case of Kano State, Nigeria.” Asian Journal of Multidisciplinary Studies 5, no. 7 (2017): 142-147.

Hackett, Rosalind I.J. and Benjamin F. Soares, eds. New Media and Religious Transformations in Africa. Bloomington, IN: Indiana University Press, 2015.

Haneef, Mohamed Aslam et al. "Integration of Waqf-Islamic Microfinance Model for Poverty Reduction: The Case of Bangladesh." International Journal of Islamic and Middle Eastern Finance and Management 8, no. 2 (2015): 246-270.

Hanretta, Sean. Islam and Social Change in French West Africa: History of an Emancipatory Community. Cambridge: Cambridge University Press, 2009.

Hasan, Samiul, ed. Human Security and Philanthropy: Islamic Perspectives and Muslim Majority Country Practices. New York: Springer, 2015.

Hoque, Nazamul, Mohammed Aktaruzzaman Khan and Khazi Deen Mohammed. "Poverty Alleviation by Zakah in a Transitional Economy: A Small Business Entrepreneurial Framework." Journal of Global Entrepreneurship Research 5, no. 7 (2015): 1-20.

Hunwick, John. "Islamic Financial Institutions: Theoretical Structures and Aspects of Their Application in Sub-Saharan Africa." In Credit, Currencies and Culture, eds. Endre Stiansen and Jane Guyer, 72-96. Uppsala: Nordiska Afrikainstitutet, 1999.

ILO. "Annex B: Situational Analysis on Zakat and Other Religious Provision in Zanzibar." In International Labour Office, Social Security Department, Zanzibar: Social Protection Expenditure and Performance Review and Social Budget, 209-220. Geneva: ILO, 2010.

Islamic Research and Training Institute. Islamic Social Finance Report, 15 June 2015. http://www.irti.org/English/Research/Documents/IDB\%20 
GLOBAL\%20FORUM\%20ON\%20ISLAMIC\%20FINANCE/10th_Global_ Forum/Islamic\%20Social\%20Finance\%20Report.pdf.

Ismail, Zenobia. Using Zakat for International Development. K4D Helpdesk Report. Birmingham: Birmingham University, 2018.

Kaag, Mayke. "Aid, Umma, and Politics: Transnational Islamic NGOs in Chad." In Islam and Muslim Politics in Africa, eds. Benjamin F. Soares and René Otayek, 85-102. New York and Basingstoke: Palgrave Macmillan, 2007.

Khan, Niaz Ahmed and Sultana Jareen. "The Waqf and Human Security in Muslim Majority Countries: Traditions, Modern Practices, and Challenges." In Human Security and Philanthropy: Islamic Perspectives and Muslim Majority Country Practices, ed. Samiul Hasan, 183-204. New York: Springer, 2015.

Kroessin, Mohammed R. and Abdulfatah S. Mohamed. "Saudi Arabian NGOs in Somalia: 'Wahhabi' Da'wah or Humanitarian Aid?” In Development, Civil Society and Faith-Based Organisations, eds. Gerard Clarke and Michael Jennings, 187-213. Basingstoke and New York: Palgrave Macmillan, 2008.

Kuran, Timur. "Islamic Redistribution Through Zakat: Historical Record and Modern Realities." In Poverty and Charity in Middle Eastern Contexts, eds. Michael Bonner, Mime Ener and Amy Singer, 275-293. Albany, NY: State University of New York Press, 2003.

Kuran, Timur. Islam and Mammon: The Economic Predicaments of Islamism. Princeton, NJ: Princeton University Press, 2004.

Kuran, Timur. Zakat: Islam's Missed Opportunity to Limit Predatory Taxation. Economic Research Initiatives at Duke (ERID) Working Paper No. 284, 8 April 2019. Available at http://dx.doi.org/10.2139/ssrn.3368292.

Lang, Sabine. NGOs, Civil Society, and the Public Sphere. Cambridge: Cambridge University Press, 2012.

Last, Murray. "Charisma and Medicine in Northern Nigeria." In Charisma and Brotherhood in African Islam, eds. D. B. Cruise O'Brien and C. Coulon, 183204. Oxford: Clarendon Press, 1988.

Launay, Robert, ed. Islamic Education in Africa: Writing Boards and Blackboards. Bloomington, IN: Indiana University Press, 2016.

Launay, Robert and Benjamin F. Soares. "The Formation of an 'Islamic Sphere' in French Colonial West Africa." Economy and Society 28, no. 4 (1999): 497-519.

LeBlanc, Marie Nathalie and Benjamin Soares, eds. Muslim West Africa in the Age of Neoliberalism. Bloomington, IN: Indiana University Press, 2008.

LeBlanc, Marie Natalie and Louis Audet Gosselin, eds. Faith and Charity: Religion and Humanitarian Assistance in West Africa. London: Pluto Press, 2016.

LeBlanc, Marie Natalie and Louis Audet Gosselin. "Introduction: Faith, Charity and the Ethics of Voluntarism in West Africa." In Faith and Charity: Religion 
and Humanitarian Assistance in West Africa, eds. Marie Natalie LeBlanc and Louis Audet Gosselin, 1-23. London: Pluto Press, 2016.

Leurs, Robert, Peter Tumaini-Mungu and Abu Mvungi. Mapping the Development Activities of Faith-Based Organizations in Tanzania. Religions and Development Research Programme Working Paper 58. Birmingham: University of Birmingham, International Development Department, 2011.

Loimeier, Roman. Islamic Reform and Political Change in Northern Nigeria. Evanston, IL: Northwestern University Press, 1997.

Loimeier, Roman. "Traditions of Reform, Reformers of Tradition: Case Studies from Senegal and Zanzibar/Tanzania." In Diversity and Pluralism in Islam: Historical and Contemporary Discourses Amongst Muslims, ed. Zulfiqar Hirji, 135-164. London: I.B. Tauris, 2010.

Loimeier, Roman. Muslim Societies in Africa: A Historical Anthropology. Bloomington, IN: Indiana University Press, 2013.

Loimeier, Roman. Islamic Reform in 20th Century Africa. Edinburgh: Edinburgh University Press, 2016.

Lubeck, Paul M. and Bryana Britts. "Muslim Civil Society in Urban Public Spaces: Globalization, Discursive Shifts, and Social Movements." In Understanding the City: Contemporary and Future Perspectives, eds. John Eade and Christopher Mele, 305-334. Oxford: Blackwell, 2002.

Lynch, Cecilia. "Local and Global Influences on Islamic NGOs in Kenya." Journal of Peacebuilding \& Development 6, no. 1 (2011): 21-34.

Mannan, M.A. "The Economics of Poverty in Islam with Special Reference to Muslim Countries." In Distributive Justice and Need Fulfilment in an Islamic Economy, ed. Munawar Iqbal, 251-286. Islamabad and Leicester: International Institute of Islamic Economics and The Islamic Foundation, 1988.

May, Samantha. "Political Piety: The Politicization of Zakat." Middle East Critique 22, no. 2 (2013): 149-164.

Miftah, Mukerrem. "Poverty and Zakat: The Feasibility of Institutionally Administering Zakat in Ethiopia.” In 3rd International ILEM Summer School 2015: Social Justice and Poverty in Muslim World, Proceedings, 235-244.

Mkuu, Khatib Mjaka and Mohd Effandi Bin Yusoff. "Zakat Institution: An Alternative for Poverty Alleviation in Zanzibar." European Journal of Business and Management 9, no. 14 (2017): 57-63.

Muhammad, Sheriff Ibrahim and Aliyu Muhammad Dahiru. "In Search of an Effective Zakat Distribution System in Kano State Nigeria." Journal for Studies in Management and Planning 1, no. 7 (2015): 345-368.

Müller, Dominik M. "From Consultancy to Critique: The 'Success Story' of Globalized Zakat Management in Malaysia and Its Normative Ambiguities.” Globalizations 14, no. 1 (2016): 81-98. 
Müller, Sebastian. "Krisen und Glaube-Streiflichter islamischer Nothilfe und langfristiger Entwicklungsmaßnahmen im Namen des Islams." In Krisenhilfe oder Hilfe in Krisen? Entwicklungszusammenarbeit mit Krisenländern, eds. Rainer Öhlschläger und Hartmut Sangmeister, 97-116. Badan-Baden: Nomos, 2016.

Nejima, Susumu, Egbert Harmsen and Masayuki Akutsu. "Introduction." In NGOs in the Muslim World: Faith and Social Services, ed. Susumu Nejima, 1-16. London and New York: Routledge, 2016.

Odabare, Ebenezer. "Civil Society in Sub-Saharan Africa." In The Oxford Handbook of Civil Society, ed. Michael Edwards, 183-194. Oxford: Oxford University Press, 2011.

Odumosu, Olakunle, Rasheed Olaniyi and Sunday Alonge. Mapping the Activities of Faith-Based Organizations in Development in Nigeria. Religions and Development Research Programme Working Paper 38. Birmingham: University of Birmingham, International Development Department, 2009.

Ostien, Philip, comp. and ed. Sharia Implementation in Northern Nigeria 1999-2006: A Sourcebook, Further Documentary Materials III: Zakat and Endowment Boards and Committees. Ibadan: Spectrum Books, 2007.

Petersen, Marie Juul. "Trajectories of Transnational Muslim NGOs." Development in Practice 22, nos. 5-6 (2012): 763-778.

Petersen, Marie Juul. For Humanity or For the Umma? Aid and Islam in Transnational Muslim NGOs. London: Hurst, 2015.

Petersen, Marie Juul. "International Muslim NGOs: 'Added Value' or an Echo of Western Principles and Donor Wishes?" In The New Humanitarians in International Practice: Emerging Actors and Contested Principles, eds. Zeynep Sezgin and Dennis Dijkzeul, 259-281. London and New York: Routledge, 2016. Pierce, Justin. "The Role and Governance of Islamic Faith Organisations in South Africa." In Charities in the Non-Western World: The Development and Regulation of Indigenous and Islamic Charities, eds. Rajeswary Ampalawar Brown and Justin Pierce, 40-64. Abingdon, Oxon and New York: Routledge, 2013 .

al-Qardawi, Yusuf. Figh az-Zakat. A Comprehensive Study. The Rules, Regulations and Philosophy of Zakat in the Light of the Qur'an and Sunna. London: Dar Al Taqwa, 1999.

Rasheed, Fatima. "Microfinance Institutions and Human Security in Muslim Majority Countries: Achievements and Challenges." In Human Security and Philanthropy: Islamic Perspectives and Muslim Majority Country Practices, ed. Samiul Hasan, 205-230. New York: Springer, 2015.

Saggiomo, Valeria. "Islamic NGOs in Africa and Their Notion of Development: The Case of Somalia." Storicamente 8 (2012): 1-12.

Salih, M.A. Mohammed. Islamic NGOs in Africa: The Promise and Peril of Islamic Voluntarism. Copenhagen: University of Copenhagen, Centre of African Studies, 2001, revised version 2002. 
Salim, Arskal. The Shift in Zakat Practice in Indonesia: From Piety to an Islamic Socio-Political-Economic System. Chiang Mai: Silkworm Books, 2008.

Sanyinna, Abubakar Yusuf and Muhammad Farihal Osman. "Analytical Overview of the Role Played by Waqf in Poverty Alleviation: A Case Study of Sokoto State, Nigeria." Asian Journal of Multidisciplinary Studies 5, no. 9 (2017): 18-30.

Seesemann, Rüdiger and Benjamin Soares. "Being as Good Muslims as Frenchmen': On Islam and Colonial Modernity in West Africa." Journal of Religion in Africa 39, no. 1 (2009): 91-120.

Shaikh, S.A. "Zakat Collectible in OIC Countries for Poverty Alleviation: A Primer on Empirical Estimation." International Journal of Zakat 1, no. 1 (2016): 17-35.

Shirazi, Nasim Shah, Salman Syed Ali and Mohammed Obaidullah. "Practical Means of Integrating Zakāt and Waqf Into Poverty Reduction Agenda of OIC Member Countries." Islamic Economic Studies 25, no. 2 (2017): 63-65.

Siddiqi, Nejatullah M. Role of the State in the Economy: An Islamic Perspective. Leicester: The Islamic Foundation, 1996.

Singer, Amy. Charity in Islamic Societies. Cambridge: Cambridge University Press, 2008.

Siradag, Abdurrahman. "Benevolence of Selfishness: Understanding the Increasing Role of Turkish NGOs and Civil Society in Africa." Insight on Africa 7, no. 1 (January 2015): 1-20.

Skinner, David E. "Da'wa and Politics in West Africa: Muslim Jama'at and Non-Governmental Organisations in Ghana, Sierra Leone and The Gambia." In Development and Politics from Below: Exploring Religious Spaces in the African State, eds. Barbara Bompai and Maria Frahm-Arp, 99-130. London: Palgrave Macmillan, 2010.

Soares, Benjamin F. “The Prayer Economy in a Malian Town." Cabiers d'Études africaines 36, no. 4 (1996): 739-754.

Soares, Benjamin F. Islam and the Prayer Economy: History and Authority in a Malian Town. Edinburgh: Edinburgh University Press for the International Africa Institute, 2005.

Soares, Benjamin, ed. Muslim-Christian Encounters in Africa. Leiden: Brill, 2006.

Soares, Benjamin and Réne Otayek, eds. Islam and Muslim Politics in Africa. New York: Palgrave Macmillan, 2007.

Sohag, Kazi et al. "Can Zakat System Alleviate Rural Poverty in Bangladesh? A Propensity Score Matching Approach.” Journal of Poverty 19, no. 3 (2015): 261-277.

Stirk, Chloe. An Act of Faith: Humanitarian Financing and Zakat. Development Initiatives Briefing Paper March 2015, available at http://devinit.org/wp-content/uploads/2015/03/ONLINE-Zakat_report_V9a.pdf. 
Tok, M. Evren and Ben O'Bright. "Reproducing Spaces of Embeddedness Through Islamic NGOs in Sub-Saharan Africa: Reflections on the Post-2015 Development." African Geographical Review 36, no. 1 (2017): 85-99.

Tripp, Charles. Islam and the Moral Economy: The Challenge of Capitalism. Cambridge: Cambridge University Press, 2006.

Tyndale, Wendy R., ed. Visions of Development: Faith-Based Initiatives. Abingdon, Oxon and New York: Routledge, 2016 [2006].

United Nations Development Programme, Istanbul International Center for Private Sector Development and Islamic Research and Training Institute. I For Impact: Blending Islamic Finance and Investing for the Global Goals, March 2017. http://www.irti.org/English/News/Documents/IRTI_UN_ Islamic_Financial_Report.pdf.

Wali, H.N. "Utilization of Zakat and Islamic Endowment Funds for Poverty Reduction: A Case Study of Zakat and Hubsi Commission, Kano State Nigeria." Journal of Economics and Sustainable Development 4, no. 18 (2013): 141-147.

Wallace, Adryan. "Agency Through Development: Hausa Women's NGOs and CBOs in Kano, Nigeria." Feminist Economics 20, no. 4 (2014): 281-305.

Weiss, Holger. Obligatory Almsgiving: An Inquiry into Zakât in the Pre-colonial Bilad al-Sûdân. Helsinki: Finnish Oriental Society, 2003.

Weiss, Holger. Begging and Almsgiving in Ghana: Muslim Positions Towards Poverty and Distress. Uppsala: Nordiska Afrikainstitutet, 2007.

Whitfield, Lindsay. "Civil Society as Idea and Civil Society as Process: The Case of Ghana." Oxford Development Studies 31, no. 3 (2003): 379-400.

World Bank and Islamic Development Bank Group. Global Report on Islamic Finance-Islamic Finance: A Catalyst for Shared Prosperity? Washington, DC: World Bank Group, 2016.

Yasmin, Sofia and Roszaini Haniffa. "Accountability and Narrative Disclosure by Muslim Charity Organisations in the UK." Journal of Islamic Accounting and Business Research 8, no. 1 (2017): 70-86.

Zakât Foundation of America. The Zakât Handbook: A Practical Guide for Muslims in the West. Bloomington, IN: AuthorHouse, 2008.

de Zayas, Farishta G. The Law and Philosophy of Zakat (The Islamic Social Welfare System). Damascus: Al-Jadidah Printing Press, 1960.

Ziddy, Issa Haji. "Review of the Waqf and Trust Commission (WTC) in Zanzibar." Inquiry: Sarajevo Journal of Social Sciences 1 (2015): 29-45.

Zulkhibri, Muhamed. "Financial Inclusion, Financial Inclusion Policy and Islamic Finance." Macroeconomics and Finance in Emerging Market Economies 9, no. 3 (2016): 303-320. 
Open Access This chapter is licensed under the terms of the Creative Commons Attribution 4.0 International License (http://creativecommons.org/licenses/ by $/ 4.0 /$ ), which permits use, sharing, adaptation, distribution and reproduction in any medium or format, as long as you give appropriate credit to the original author(s) and the source, provide a link to the Creative Commons licence and indicate if changes were made.

The images or other third party material in this chapter are included in the chapter's Creative Commons licence, unless indicated otherwise in a credit line to the material. If material is not included in the chapter's Creative Commons licence and your intended use is not permitted by statutory regulation or exceeds the permitted use, you will need to obtain permission directly from the copyright holder.

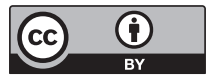

